\title{
What are the indicators of a successful business rescue in South Africa? Ask the business rescue practitioners
}

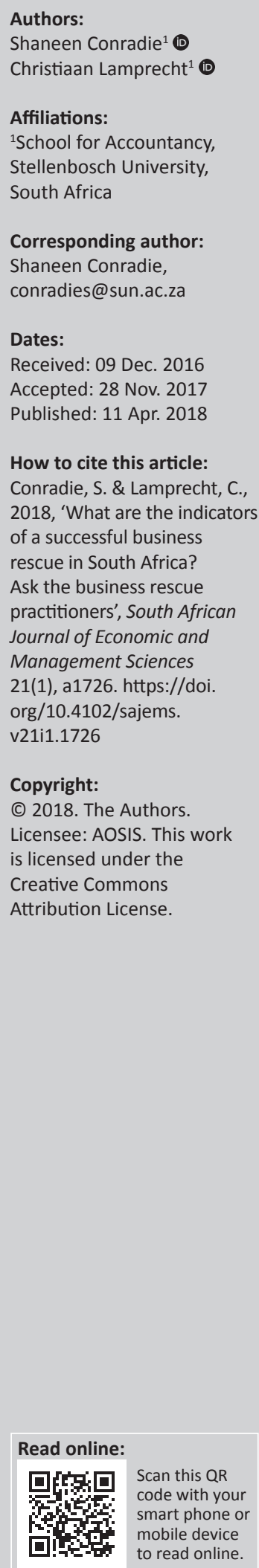

Background: Business rescue, in terms of Chapter 6 of the Companies Act No 71 of 2008, is still relatively new to the South African business environment. The need for a successful business rescue regime is beyond doubt. However, a consistent manner to measure the success of the regime has not been determined. Previous research into possible indicators of business rescue success was based on a review of international business rescue regimes that share the same underlying philosophy as the South African business rescue regime.

Aim and Setting: This study extends previous research efforts by soliciting the opinions of 16 South African, senior business rescue practitioners on the indicators of business rescue success.

Method: The researchers used a qualitative research approach. The Delphi research technique was used to gather qualitative and quantitative empirical data from business rescue practitioners.

Results: The experts reached a high level of consensus on various indicators of a successful business rescue. Most notable are that business rescue should save as many jobs as possible and that the actual outcome should be compared to that estimated in the business rescue plan. A novel indicator of success is the business rescue points saved or rescued, when using the public interest score.

Conclusion: The study makes a valuable contribution to the debate on what constitutes a successful business rescue by adding the considered opinion on indicators of success by one group of experts in the field of business rescue, namely senior business rescue practitioners.

\section{Introduction}

The South African business rescue regime was introduced with the enactment of the new Companies Act, Act 71 of 2008. Various financially-troubled South African companies have since used this lifeline in an attempt to survive and avoid liquidation. The success of business rescue as a lifeline is important to numerous stakeholders in the business, such as employees, creditors, lenders, post-commencement financiers and shareholders. Furthermore, the effectiveness of the regime in successfully achieving its goals is also important to the legislative authority. However, exactly what constitutes a successful business rescue is not clear (Pretorius 2015:33) and has proven to be elusive. Current statistics on success have been described as 'inconsistent with unreliable validity' (Pretorius 2015:32).

Conradie and Lamprecht (2015:18) researched the international business rescue arena for indicators of success. Based on the similarities of the international regime to the South African regime, they suggested a broad list of indicators that could be used to measure success in the South African context. However, Conradie and Lamprecht did not specifically research the suitability of these business rescue success indicators in a South African setting and against the opinions of one of the most important parties in a rescue attempt, the business rescue practitioner. Furthermore, several research papers on the South African business rescue model, which may contain further success indicators, have appeared as from 2015. The aim of this study is therefore first, to add any success indicators, sourced from the latest research on the topic, to the current list of international-based success indicators, and second, to engage with South African senior business rescue practitioners, as experts in this field, in order to obtain their opinions on those indicators that would be suitable in the South African business rescue environment. Their specialist knowledge in business rescue could add significant insight with regard to identification of a local context-specific list of success indicators that can be used to further develop a set of business rescue success verifiers. These verifiers can serve as a useful management tool in order to measure business rescue success rates in South Africa with accuracy. 


\section{Problem statement}

South Africa has unique economic and employment conditions. Chapter 6 was written with these socio-economic conditions in mind (Swart 2014:419). The indicators that Conradie and Lamprecht (2015) identified from international literature may not all be perceived as equally important in South Africa.

In this sequential study it was therefore important to first, review current research on the topic of business rescue success for any additional indicators of success, and second, consult South African business rescue practitioners, as experts in this field, to assist with compiling a South African relevant set of business rescue success indicators. In this study, an 'indicator' refers to that which indicates the state or level of something (Oxford Dictionary 2017), for example, the substantial implementation of an approved business rescue plan may be an indicator of success.

If such a relevant list of indicators could be created with input from experts in the field, related verifiers may paint a more accurate picture of business rescue success. Accurate business rescue statistics would, in turn, lead to better decision making by stakeholders in business rescue.

\section{Aim of the study and research questions}

The aim of the study was to reach a high level of consensus on what top business rescue practitioners, the experts who are actively involved in the application and execution of the business rescue legislation in South Africa, would consider as indicators of a successful business rescue in South Africa. Therefore, the following research questions were formulated in order to achieve the research aim:

- What, according to business rescue practitioners, are the goals of business rescue?

- What, according to business rescue practitioners, are the indicators of a successful business rescue?

\section{Research design}

In order to answer the research questions and achieve the research aim, the research was designed as indicated in Table 1 . Table 1 is followed by a brief discussion of the research design.

The previous section indicated that the research was aimed at establishing the indicators of a successful business rescue. Research questions were formulated to achieve the research aim. The research aim and questions were exploratory in nature and the study followed an inductive mode of reasoning to generate new insights. The conceptualisation was a-theoretical, and achieving the research aim would contribute to the theory discovery as the research concepts emerge gradually during the data collection process (Mouton 2001:152; Olalere 2011:22).
TABLE 1: Research design components.

\begin{tabular}{|c|c|}
\hline Component & Description \\
\hline Purpose & Exploratory \\
\hline $\begin{array}{l}\text { Conceptualisation and } \\
\text { mode of reasoning }\end{array}$ & A-theoretical and inductive \\
\hline Research paradigm & $\begin{array}{l}\text { Ontology: Constructionism } \\
\text { Epistemology: Interpretivism }\end{array}$ \\
\hline Research approach & Qualitative (application of grounded theory principles) \\
\hline $\begin{array}{l}\text { Research question } \\
\text { or problem }\end{array}$ & $\begin{array}{l}\text { - What, according to business rescue practitioners, are } \\
\text { the goals of business rescue, and } \\
\text { - On which indicators of a successful business rescue } \\
\text { can business rescue practitioners reach consensus? }\end{array}$ \\
\hline Context & Business rescue in South Africa \\
\hline Propositions & $\begin{array}{l}\text { 1. The goals of business rescue are clear; } \\
\text { 2. Business rescue practitioners can reach a high level } \\
\text { of consensus on the indicators of a successful } \\
\text { business rescue. }\end{array}$ \\
\hline Phenomena investigated & $\begin{array}{l}\text { - The goals of business rescue legislation } \\
\text { - The perception of those factors that can indicate a } \\
\text { successful business rescue }\end{array}$ \\
\hline Mode of observation & $\begin{array}{l}\text { Delphi research technique (a type of structured } \\
\text { questionnaire) }\end{array}$ \\
\hline Units of observation & $\begin{array}{l}\text { - International and local indicators of business rescue } \\
\text { success } \\
\text { - Feedback and commentary obtained from business } \\
\text { rescue practitioners }\end{array}$ \\
\hline $\begin{array}{l}\text { Logic linking the data to } \\
\text { the propositions }\end{array}$ & $\begin{array}{l}\text { The goals and indicators of success of business rescue } \\
\text { are available. Business rescue practitioners are willing } \\
\text { to provide feedback and commentary on indicators of } \\
\text { what they consider to be a successful business rescue. }\end{array}$ \\
\hline Empirical data analysis & Descriptive and content analysis \\
\hline $\begin{array}{l}\text { Criteria for interpreting } \\
\text { the findings }\end{array}$ & $\begin{array}{l}\text { - Possible indicators of business rescue success can be } \\
\text { determined. } \\
\text { - South African business rescue practitioners are clear } \\
\text { on the goals of business rescue. } \\
\text { - A high level of consensus is reached between the } \\
\text { South African business rescue practitioners on what } \\
\text { the indicators of a successful business rescue are. }\end{array}$ \\
\hline
\end{tabular}

In this study, the researchers fulfilled the instrument of research role. The researchers engaged with the research participants during the primary data collection process, allowing the gathering of rich, deep data. The researchers acted as openminded keen observers of the data in order to derive meaning from it in a business rescue context. The research approach was therefore qualitative and grounded theory principles were applied in search of any themes and patterns that may have emerged from the data (Olalere 2011:18, 22).

Both researchers come from an interpretivist epistemology stance searching for a better understanding of true indicators of business rescue success in a world that is constructed socially. As an instrument of research and gatekeepers of the data collected, the researchers are aware of their own power and bias. Ethics, trustworthiness and rigour were therefore considered paramount. Ethical clearance for the study was obtained and this paper clearly explains the data collection and analysis processes followed. Being two researchers was helpful with regard to ensuring trustworthiness and rigour. Interpretation of the data was cross-checked and research rigour was achieved through a strong emphasis of rigour in documentation, procedures and ethics (Naidoo 2017:17). Documentation rigour was achieved by ensuring the existence of a correlation between the various steps in the research process, as explained later in the paper. Procedural rigour was attained by closely following the processes in the Delphi research technique, also elaborated on later in the paper. 
Regarding ethical rigour, the participants were reminded of their rights and confidentiality during the research process.

The research question of what the indicators are of a successful business rescue in the South African context is complex, as the perceived success of the regime has a financial, social, political and environmental impact. A study on business rescue success would therefore need to include experts who would understand the wider impact that business rescue might have. Experts are more likely to be correct about complex questions in their field than non-experts.

Since it was important to obtain the data from experts in the field of business rescue, a specific research technique that involves experts, namely the Delphi research technique, was employed.

\section{Application of the Delphi research technique}

The Delphi research technique can be seen as a virtual panel discussion among experts. The objective of the Delphi research technique is to obtain a satisfactory degree of consensus from a group of experts. This method works well in a situation where it is necessary to obtain information that is subjective (Okoli \& Pawlowski 2004:16). According to Gordon (1994:1), bringing experts together in a normal conference room, apart from its practical challenges, has certain drawbacks. Sometimes the 'loudest voice rather than the soundest argument' may win. The Delphi research technique removes these traditional conference room weaknesses. The technique is therefore almost like a normal conference meeting where experts discuss a certain topic, but with the added benefit that panellists do not have to meet at one place, and panellists contribute anonymously to the topic under discussion.

The strength of the Delphi research technique is the effort made to obtain a satisfactory degree of consensus among the experts. This aim is achieved by administering two or more rounds of research questionnaires (Skulmoski, Hartman \& Krahn 2007:11). Researchers also often make use of pilot studies in drafting a questionnaire. According to Skulmoski et al. (2007:4), pilot studies can be effective for various reasons, two of which are to help with the design of the study and to improve the research instrument, in this case, the research questionnaire.

In a Delphi study, the respondents consist of a panel of experts selected based on their expertise. The idea is therefore not to have a sample that is representative of a population, but rather to select those with expert knowledge in the area of consideration (Skulmoski et al. 2007:4). A panel size of 10-18 individuals is deemed appropriate in a Delphi study (Okoli \& Pawlowski 2004:19).

Once a panel is selected, questionnaires are sent out to each participant, and individual data are gathered. Skulmoski et al. (2007:10) state that the first questionnaire can be very broad, or it can be narrowed down to guide panellists toward a certain aim. In order to obtain the most data from panellists,

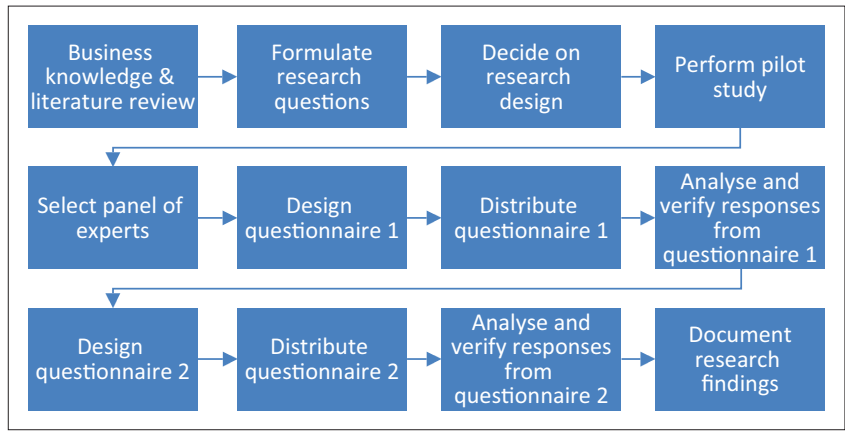

Source: Adapted from Skulmoski, G.J., Hartman, F.T. \& Krahn, J., 2007, ‘The Delphi method for graduate research', Journal of Information Technology Education 6, 3. https://doi. org/10.28945/199

FIGURE 1: Application of the Delphi research technique in this study.

an open-ended questionnaire is deemed most appropriate. Furthermore, the first questionnaire of a Delphi study is often seen as the 'brainstorming' stage (Okoli \& Pawlowski 2004:24). As soon as experts return the first questionnaire, the researchers analyse the responses received and, based on the feedback received in the first questionnaire, design the second questionnaire. Questionnaires are sent out repeatedly until the research questions are answered, a certain degree of consensus is obtained, or 'theoretical saturation' is accomplished (Skulmoski et al. 2007:11).

It is important to note that at no stage will an expert know the identity of other panel members. Only the researchers possess this information. However, the panel members will receive the (anonymous) responses or comments made by other panel members in the previous round, and will have the opportunity to respond to these responses or comments. The fact that the researchers know the identity of the panel members means that the researchers can clarify vague responses. The data obtained in such a way is perceived to have more 'richness' (Okoli \& Pawlowski 2004:18).

The final step of the Delphi research technique is to document the results of the data obtained from the panel of experts through the various questionnaire rounds. Data verification is inherently done by the panellists each time a new questionnaire is distributed. Figure 1 summarises the Delphi research technique as it was applied in this study.

In this study, saturation was achieved after two rounds of questionnaire distribution. The next section describes the execution of the Delphi research technique in this study.

\section{Execution of the Delphi research technique}

In order to draw reliable conclusions from the research findings, the research should be executed with rigour and in line with the particular technique followed. This section briefly describes each of the steps - as indicated in Figure 1that was followed in conducting the research.

\section{Business knowledge and literature review}

The authors of this paper have a keen academic interest in the business rescue industry. As researchers, over the years they 
have gained a collective understanding of the business rescue industry in South Africa by attending various workshops and courses in the field of business rescue and turnarounds. The comprehensive literature review used by Conradie and Lamprecht (2015) provided a valuable starting point for this study. In particular, the limitations of their study, as indicated in the introduction to this paper, exposed the research gap and research problem addressed in this study.

Conradie and Lamprecht (2015:20) identified international success criteria, with some only used in the United States of America (USA). Six of the indicators relate to the 'going concern' criterion, the main indicator being the number (or percentage) of going concern entities that exit the reorganisation, restructuring or rescue. Other indicators identified under the going concern criterion were indicators measuring success after the reorganisation, that is, to establish economic viability in the short- to long term. Two indicators related to maximising the 'creditor return' criterion were found, namely, substantial implementation of the plan, and the comparison of the actual return to the liquidation return. The final two indicators referred to the criterion to consider the impact on all stakeholders, and here, change in asset size and whether key operation was still in one company were considered.

In addition to the above indicators of success, local literature on Chapter 6 business rescue success for the period January 2011 to September 2017 were also reviewed with the aim to extend the list of possible indicators of success. Interestingly, Loubser (2013:442) states that Chapter 11 successes might be regarded as failure in South Africa. Moreover, Searle (2013:15) talks about the perceived success of Chapter 11, indicating that we cannot rely blindly on success indicators used by foreign researchers. A summary of our review of local literature, that mention the definition of success or indicators of success, are presented in Table 2.

In additional to the above, Calitz and Freebody (2016), Du Preez (2013), Noomé (2014), Prior (2014:71), Reineck (2015)

TABLE 2: Summary of local literature referring to business rescue success.

\begin{tabular}{|c|c|}
\hline Success indicator mentioned in research & Source \\
\hline $\begin{array}{l}\text { The business continuing on a solvent } \\
\text { and liquid basis }\end{array}$ & $\begin{array}{l}\text { - Bradstreet (2011:380), } \\
\text { - Deloitte (2017:27), } \\
\text { - Naidoo (2016:41). }\end{array}$ \\
\hline Better return for creditors & $\begin{array}{l}\text { - Deloitte (2017:27), } \\
\text { - Naidoo (2016:41). }\end{array}$ \\
\hline $\begin{array}{l}\text { A sustainable business with debts and } \\
\text { stakeholder expectations addressed }\end{array}$ & $\begin{array}{l}\text { - Deloitte (2017:27), } \\
\text { - Naidoo (2016:41). }\end{array}$ \\
\hline Approval of the plan & - Naidoo (2016:41). \\
\hline Substantial implementation of the plan & $\begin{array}{l}\text { - Bezuidenhout (2012:46), } \\
\text { - Commission (2014), } \\
\text { - Deloitte (2017:27), } \\
\text { - Lebeloane (2017:43), Naidoo (2016:40). }\end{array}$ \\
\hline $\begin{array}{l}\text { Going concern sale, take-over or } \\
\text { merger }\end{array}$ & $\begin{array}{l}\text { - Maphiri (2015:2), } \\
\text { - Pretorius (2015:21). }\end{array}$ \\
\hline Saving of jobs & $\begin{array}{l}\text { - Deloitte (2017:27), } \\
\text { - Naidoo (2016:40), } \\
\text { - Pretorius (2015:21). }\end{array}$ \\
\hline $\begin{array}{l}\text { Consideration of what happens after } \\
\text { the rescue }\end{array}$ & $\begin{array}{l}\text { - Burke-le Roux and Pretorius (2017:2), } \\
\text { - Naidoo (2016:40). }\end{array}$ \\
\hline
\end{tabular}

Note: Please see the full reference list of the article, Conradie, S. \& Lamprecht, C., 2018, 'What are the indicators of a successful business rescue in South Africa? Ask the business
rescue practitioners', South African Journal of Economic and Management Sciences 21(1), a1726. https://doi.org/10.4102/sajems.v21i1.1726, for more information. and Vanderstraeten (2016:25) all looked at the importance of post-commencement finance for business rescue success. However, the implied success indicator in this instance is assumed to be a solvent, liquid, going concern.

Naidoo (2016:6, 66) concludes that a 'lack of clarity' in the definition of success still exists, which may result in the legislation to be underestimated. As observed from the above literature, consensus on the definition of Chapter 6 success is not yet reached, which leaves room for further investigation. The success indicators documented in Table 2 were already directly or implicitly included in the list of potential indicators identified from the international literature, resulting in no addition of new indicators of success from local literature. The first round of the Delphi questionnaire therefore included success indicators identified from literature as well as the result of a pilot study.

\section{Research question}

In order to answer the main research question, the goals of business rescue first needed to be established, followed by the potential success indicators to measure achievement of the goals. Two business rescue goals are indicated in Chapter 6 . The Act states that business rescue provides proceedings to facilitate the rehabilitation of a financially distressed company. The proceedings allow for temporary supervision in order to develop and implement a plan that maximises the likelihood of the company continuing in existence on a solvent basis (Goal 1) or, if that is not possible, results in a better return for the company's creditors or shareholders than would result from the immediate liquidation of the company (Goal 2) (Republic of South Africa 2008). However, Conradie and Lamprecht $(2015: 18,22)$, identified a third implied goal, namely that the impact on all stakeholders should be beneficial, and that especially in South Africa the interest of employees should be protected.

In view of the above-mentioned goals of business rescue, the main research question, namely, 'What, according to business rescue practitioners, are the indicators of a successful business rescue?', was formulated using the researchers' own knowledge and insights gained from studying the above-mentioned literature.

\section{Deciding on research design}

As indicated in Figure 1, the next step in applying the Delphi technique is to decide on the research design. See 'Research Design' and Table 1 for an explanation of the research design followed within the context of the Delphi technique.

\section{Pilot study}

Since the Delphi research technique allows the first questionnaire to be narrowed down to guide panellists toward a certain aim, which is to establish what expert business rescue practitioners would consider as a successful business rescue, a pilot study was first performed. Two experts in the business rescue industry were invited to participate in the pilot study interview. The experts were 
identified from the Companies and Intellectual Property Commission [CIPC]'s list of business rescue practitioners (see the next section on the selection of the panel of experts) and are well known in the industry. Their selection was further complemented by reports in the printing media on their appointment to high level business rescue cases. The purpose of the pilot study interviews was to ascertain the relevance of the main research question, to establish the appropriateness of the draft list of success indicators as a point of departure, and to discuss the best way to present and communicate the first research questionnaire.

Individual meetings were held with each of the two expert business rescue practitioners. Both experts confirmed the relevance of the research questions and applicability of the draft list of success indicators as a point of departure. However, the experts suggested a few additional business rescue success criteria for inclusion in the first questionnaire (Anonymous Expert A 2016; Anonymous Expert B 2016).

\section{Selection of the panel of expert practitioners}

A database with names and contact details of all registered and licenced business rescue practitioners was obtained from the CIPC's website (CIPC 2015). The database of practitioners consisted of junior, experienced, and senior practitioners. Because the intention of the study was to obtain insight from expert practitioners, only senior business rescue practitioners were considered for inclusion in the panel. Recent media reports on business rescue cases were further scrutinised to identify individuals or firms that were involved in the rescue of listed companies, as these types of rescues are more complex and require the most experienced practitioners.

The various business rescue practitioners that were identified through the use of media reports were matched with the CIPC's list of senior business rescue practitioners. A short list of 18 experts of the most experienced senior business rescue practitioners was prepared and these experts were invited to form part of the Delphi panel, including both practitioners from the pilot study. The final panel consisted of 16 business rescue experts. The panel members included chartered accountants, accountants, engineers and lawyers. Furthermore, the experts represented various boutique business rescue firms and three of the 'big four' accounting firms in South Africa. These senior business rescue practitioners have proven business rescue and turnaround experience, as evidenced from them being vetted by the CIPC, as well as a wide-ranging knowledge of the financial, social, political and environmental impact of business rescue in South Africa.

\section{Questionnaire 1: Design}

The main disadvantage of the Delphi technique is that a multi-round study requires more time and, as a result, some participants will drop out during the process (Gordon 1994:9). In order to make the best use of the experts' time, and in line with the insights gained from the pilot study interviews, the researchers decided that the option of a guided questionnaire for round one would be better suited than an open-ended questionnaire type. The rationale was that if consensus on certain success indicators could already be reached in Questionnaire 1, the number of questionnaire rounds would be reduced, resulting in less of the experts' time being needed to conclude the study and a higher panel retention rate.

According to Dudley, Plumly and Knoblock (1999:58), a measurement tool should be based on an organisation's goals. Once the goals are established and agreed on, the measurement criteria can be formulated. Jones (2012) points out that an indicator can serve as a useful proxy until a measure is developed. The aim of this study was just that, namely to establish those indicators of business rescue success that could be used in future research to develop a scorecard or measurement tool. In order to establish the goals, present the preliminary business rescue success indicators and obtain new indicators, Questionnaire 1 was divided into three sections.

In the first section, panellists were asked to indicate whether they 'agree' or 'disagree' with the three indicated goals (two from Chapter 6 and one implied goal) discussed earlier. Additional space was provided with each goal to allow for any suggestions or amendments that the panellists believed were necessary.

The second section of the questionnaire presented the preliminary indicators of a successful business rescue. With respect to each of the success indicators, the panellists had to respond by choosing one of the following four options: 'agree', 'completely agree', 'disagree' or 'completely disagree'. Furthermore, an open-text box was available for every success indicator where the panellist could enter any comments.

The third section of the questionnaire was an open-ended question, where panellists were asked to list any other additional indicators that should be included when the success of a business rescue is considered. This section was included in order to ensure that any other possible indicators of a successful business rescue that may not already be on the questionnaire is identified for inclusion in the second questionnaire (see 'Questionnaire 2: Design').

\section{Questionnaire 1: Distribution}

Questionnaire 1 was distributed to each of the 16 panel members by way of an electronic web-based survey system. All the completed questionnaires were received within three weeks.

\section{Questionnaire 1: Analysis and verification of responses}

The feedback received from each of the 16 panellists was evaluated and some vague comments noted. These comments were clarified with the specific panellist via e-mail or telephonically as far as possible. All responses and comments were summarised and documented in a report, including additional success indicators suggested by the panel members. The researchers noted that consensus was already reached on a number of indicators of a successful business rescue. 


\section{Questionnaire 2: Design}

The Delphi research technique allows panellists to change their opinion, should they wish to, once they learn what the summarised opinions of other panel members are, as well as to consider additional success indicators suggested by the panel members in previous questionnaires (Skulmoski et al. 2007:4). Questionnaire 2 was therefore based on the data obtained from Questionnaire 1 and included the additional measurement criteria that were suggested by panellists in Questionnaire 1. An individual report was prepared for each panellist indicating his or her response and the aggregate percentage of panellists who strongly disagreed and disagreed and those who strongly agreed and agreed for each of the success indicators in Questionnaire 1.

In order to maximise the panellists' available time, a separate report was also prepared with excerpts of those success indicators where the panellists did not reach consensus. The excerpts also included the summarised comments for each of the success indicators. The rationale for including the summarised comments was to give all panellists the opportunity to evaluate the arguments of other panel members, and then to change their own statement now that they had seen the arguments made by other panel members, should they wish to do so. It should be noted that the identity of panellists remained anonymous to the other panellists at all times.

\section{Questionnaire 2: Distribution}

Questionnaire 2 consisted of two sections, namely a full report and an excerpt with the new criteria identified by other panellists. The full report indicated the panellists' individual responses as opposed to the aggregate responses for each of the business rescue success criteria. The rationale for the second section was to focus the panellists' time on the new criteria as well as only those criteria from Questionnaire 1 where consensus had not been reached.

With respect to the second section, the panellists were requested to:

- Respond to the new criteria identified by other panellists in the same manner as in Questionnaire 1, namely to indicate whether they 'completely disagree', 'disagree', 'agree' or 'completely agree';

- Review the areas where their own opinion differed from the others panellists by assessing the comments other panellists made, and to change their original response, should they wish to do so.

The panellists were also given the opportunity to review their answers for those criteria where consensus had already been reached, should they wish to do so. The response time for Questionnaire 2 was much longer than the response time for Questionnaire 1. The researchers had to follow up with various e-mails or telephonic requests to obtain the feedback of all panellists.

\section{Questionnaire 2: Analysis and verification of responses}

The individual responses made by each panellist were evaluated by the researchers and again clarified where necessary. Twelve of the 16 panellists reviewed their responses. After the second round it was noted that theoretical saturation and a high level of consensus were reached, and no further questionnaire iterations were deemed necessary.

\section{Documentation of research findings}

The value of the Delphi method rests with the ideas it generates (Gordon 1994:3), and the documentation of research findings is the last step of the Delphi research technique. In the process of analysing and documenting responses, miscommunication between the researchers and the panellists can be a limitation. Some of the ideas (success indicators) could have been misunderstood by the panellists when they completed the questionnaires. Equally, some of the comments received from panellists could have been misunderstood by the researchers. The above limitation was minimised due to the fact that the researchers followed up on unclear comments before documenting the final results. The research findings are presented below.

\section{Research findings}

The results below represent the views of the panellists after they had the opportunity to revise their original opinion.

\section{Findings related to Proposition 1: The goals of business rescue are clear}

The first section of Questionnaire 1 dealt with the first research question, namely 'What, according to business rescue practitioners, are the goals of business rescue?'. Table 3 summarises the results with respect to the first research question.

\section{Note 1}

$81 \%$ of the panel supported this statement. The three dissenting panellists indicated that the legal entity is of little concern, and that the emphasis should not be on 'company' but rather on 'business'; in other words, on the staff and its trading assets. The rest of the panel supported this statement (also refer to Note 14).

TABLE 3: The goals of business rescue.

\begin{tabular}{|c|c|c|c|}
\hline Goals of business rescue & Variable & $\begin{array}{l}\text { Panel } \\
\text { response (\%) }\end{array}$ & Note $\dagger$ \\
\hline \multirow{2}{*}{$\begin{array}{l}\text { Goal 1: The company should emerge } \\
\text { from the business rescue as a going } \\
\text { concern, and remain economically } \\
\text { viable. }\end{array}$} & $\begin{array}{l}\text { Agree \& strongly } \\
\text { agree }\end{array}$ & 81 & \multirow[t]{2}{*}{1} \\
\hline & $\begin{array}{l}\text { Disagree \& } \\
\text { strongly disagree }\end{array}$ & 19 & \\
\hline \multirow{2}{*}{$\begin{array}{l}\text { Goal 2: If Goal } 1 \text { is not met, then } \\
\text { creditors should receive a better } \\
\text { return through the rescue regime } \\
\text { than under immediate liquidation. }\end{array}$} & $\begin{array}{l}\text { Agree \& strongly } \\
\text { agree }\end{array}$ & 94 & \multirow[t]{2}{*}{2} \\
\hline & $\begin{array}{l}\text { Disagree \& } \\
\text { strongly disagree }\end{array}$ & 6 & \\
\hline \multirow{2}{*}{$\begin{array}{l}\text { Goal 3: An implicit goal, drawn from } \\
\text { the spirit of Chapter } 6 \text {, is that } \\
\text { employees' job opportunities should } \\
\text { be protected. }\end{array}$} & $\begin{array}{l}\text { Agree \& strongly } \\
\text { agree }\end{array}$ & 100 & \multirow[t]{2}{*}{3} \\
\hline & $\begin{array}{l}\text { Disagree \& } \\
\text { strongly disagree }\end{array}$ & 0 & \\
\hline
\end{tabular}

$\dagger$, Description provided in the text 


\section{Note 2}

One expert commented that the:

'rescue should give a better return to the creditor.' (Expert 105523, 2016)

According to the letter of the law, a 'better return than immediate liquidation' is acceptable, but this expert argued that the only goal is to rescue the business, and not to end up in liquidation.

\section{Note 3}

It was interesting to note that all the experts agreed with Goal 3, since it is an implicit goal. The above results show that most of the experts were in agreement with respect to the two business rescue goals found in Chapter 6. The panel of experts also agreed that the job opportunities should be protected, which is very important. It also provides evidence for Conradie and Lamprecht's non-evidence-based suggestion that it should also be considered a goal in measuring the success of business rescue in South Africa. However, since it is not an explicit goal, the protection of employee job opportunities has been considered a criterion of success for which the saving of a substantial number of jobs would be an indicator for business rescue success.

Since the goals had been confirmed, the next step was then to establish the indicators of a successful business rescue. The results with respect to the business rescue success indicators are presented and discussed below.

\section{Findings related to Proposition 2: Business rescue experts can reach consensus on indicators of a successful business rescue}

The second, but main research question to be answered was: 'What, according to business rescue practitioners, are the indicators of a successful business rescue?'. It was interesting to note that a high level of consensus was already reached on some of the success indicators after the first questionnaire.

The panel submitted valuable feedback on the success indicators. The success indicators and panel responses were sub-categorised under the respective goals they intend to measure, and are summarised in the tables to follow (Tables 4-7). Table 4 summarises those indicators that may deem a business rescue successful under Goal 1.

The notes below refer to the applicable indicators in Table 4 . If a high level of consensus was not reached between panellists, the comments and arguments presented by the panellists were briefly summarised for further consideration, followed by a conclusion on whether or not the indicator should be included in the final list of success indicators.

\section{Note 4}

The panellists mainly disagreed with this indicator, arguing that as business rescue fees are paid first, the inability to settle business rescue fees and costs could indicate that the
TABLE 4: Business rescue success indicators for Goal 1.

\begin{tabular}{|c|c|c|c|}
\hline $\begin{array}{l}\text { GOAL } 1 \text { (Going concern): } \\
\text { Success indicator }\end{array}$ & Variable & $\begin{array}{l}\text { Panel } \\
\text { response (\%) }\end{array}$ & Note \\
\hline \multirow{2}{*}{$\begin{array}{l}\text { The business rescue practitioner } \\
\text { received full payment for the business } \\
\text { rescue service he or she provided }\end{array}$} & $\begin{array}{l}\text { Agree \& strongly } \\
\text { agree }\end{array}$ & 31 & \multirow[t]{2}{*}{4} \\
\hline & $\begin{array}{l}\text { Disagree \& } \\
\text { strongly disagree }\end{array}$ & 69 & \\
\hline \multirow[t]{2}{*}{$\begin{array}{l}\text { The business rescue plan was } \\
\text { accepted by creditors }\end{array}$} & $\begin{array}{l}\text { Agree \& strongly } \\
\text { agree }\end{array}$ & 37 & \multirow[t]{2}{*}{5} \\
\hline & $\begin{array}{l}\text { Disagree \& } \\
\text { strongly disagree }\end{array}$ & 63 & \\
\hline \multirow[t]{2}{*}{$\begin{array}{l}\text { The approved plan was partially } \\
\text { implemented }\end{array}$} & $\begin{array}{l}\text { Agree \& strongly } \\
\text { agree }\end{array}$ & 56 & \multirow[t]{2}{*}{6} \\
\hline & $\begin{array}{l}\text { Disagree \& } \\
\text { strongly disagree }\end{array}$ & 44 & \\
\hline \multirow[t]{2}{*}{$\begin{array}{l}\text { The approved plan was substantially } \\
\text { implemented }\end{array}$} & $\begin{array}{l}\text { Agree \& strongly } \\
\text { agree }\end{array}$ & 100 & \multirow[t]{2}{*}{7} \\
\hline & $\begin{array}{l}\text { Disagree \& } \\
\text { strongly disagree }\end{array}$ & 0 & \\
\hline \multirow{2}{*}{$\begin{array}{l}\text { The distressed company exited } \\
\text { business rescue as a going concern } \\
\text { (e.g. in a liquid condition, with debt } \\
\text { being restructured) }\end{array}$} & $\begin{array}{l}\text { Agree \& strongly } \\
\text { agree }\end{array}$ & 100 & \multirow[t]{2}{*}{8} \\
\hline & $\begin{array}{l}\text { Disagree \& } \\
\text { strongly disagree }\end{array}$ & 0 & \\
\hline \multirow{2}{*}{$\begin{array}{l}\text { The company, after exiting business } \\
\text { rescue, proves to be profitable in the } \\
\text { short to medium term (e.g. based on } \\
\text { profit margins, return on assets and } \\
\text { cash flows) }\end{array}$} & $\begin{array}{l}\text { Agree \& strongly } \\
\text { agree }\end{array}$ & 94 & \multirow[t]{2}{*}{9} \\
\hline & $\begin{array}{l}\text { Disagree \& } \\
\text { strongly disagree }\end{array}$ & 6 & \\
\hline \multirow{2}{*}{$\begin{array}{l}\text { The company, after exiting business } \\
\text { rescue, proves to be economically } \\
\text { viable in the short to medium term } \\
\text { (e.g. measured by whether the } \\
\text { company subsequently re-filed } \\
\text { for business rescue) }\end{array}$} & $\begin{array}{l}\text { Agree \& strongly } \\
\text { agree }\end{array}$ & 81 & \multirow[t]{2}{*}{10} \\
\hline & $\begin{array}{l}\text { Disagree \& } \\
\text { strongly disagree }\end{array}$ & 19 & \\
\hline \multirow{2}{*}{$\begin{array}{l}\text { The company, after exiting business } \\
\text { rescue, performs in the long term on } \\
\text { par with market expectations (if it is } \\
\text { a listed company), or it matches the } \\
\text { performance of peer companies } \\
\text { (if it is an unlisted company) }\end{array}$} & $\begin{array}{l}\text { Agree \& strongly } \\
\text { agree }\end{array}$ & 88 & \multirow[t]{2}{*}{11} \\
\hline & $\begin{array}{l}\text { Disagree \& } \\
\text { strongly disagree }\end{array}$ & 12 & \\
\hline
\end{tabular}

$\dagger$, Description provided in the text

TABLE 5: Business rescue success criteria for Goal 2 (better return to creditors).

\begin{tabular}{|c|c|c|c|}
\hline $\begin{array}{l}\text { GOAL } 2 \text { (Better return to creditors): } \\
\text { Success indicator }\end{array}$ & Variable & $\begin{array}{l}\text { Panel } \\
\text { response (\%) }\end{array}$ & Note $\dagger$ \\
\hline \multirow{2}{*}{$\begin{array}{l}\text { The approved plan (to maximise the } \\
\text { return to creditors) was substantially } \\
\text { implemented }\end{array}$} & $\begin{array}{l}\text { Agree \& strongly } \\
\text { agree }\end{array}$ & 100 & \multirow[t]{2}{*}{12} \\
\hline & $\begin{array}{l}\text { Disagree \& } \\
\text { strongly disagree }\end{array}$ & 0 & \\
\hline \multirow{2}{*}{$\begin{array}{l}\text { The company was liquidated under a } \\
\text { business rescue plan, and the return } \\
\text { received under the business rescue } \\
\text { proceedings proves to be more than } \\
\text { the return that would have been } \\
\text { received from immediate liquidation }\end{array}$} & $\begin{array}{l}\text { Agree \& strongly } \\
\text { agree }\end{array}$ & 88 & \multirow[t]{2}{*}{13} \\
\hline & $\begin{array}{l}\text { Disagree \& } \\
\text { strongly disagree }\end{array}$ & 12 & \\
\hline \multirow{2}{*}{$\begin{array}{l}\text { The distressed company, or a part of } \\
\text { it, was sold to another entity, and } \\
\text { although the original legal entity may } \\
\text { no longer exist, the key operations } \\
\text { were kept alive in the new company }\end{array}$} & $\begin{array}{l}\text { Agree \& strongly } \\
\text { agree }\end{array}$ & 94 & \multirow[t]{2}{*}{14} \\
\hline & $\begin{array}{l}\text { Disagree \& } \\
\text { strongly disagree }\end{array}$ & 6 & \\
\hline
\end{tabular}

$\dagger$, Description provided in the text

TABLE 6: Business rescue success criteria for Goal 3 (employees' job opportunities should be protected).

\begin{tabular}{lll}
\hline GOAL 3: Success indicator & Variable & Panel response (\%) \\
\hline $\begin{array}{l}\text { Business rescue saved a } \\
\text { substantial number of jobs. }\end{array}$ & Agree \& strongly agree & 94 \\
& Disagree \& strongly disagree & 6 \\
\hline
\end{tabular}

business is still in distress, therefore, there could not have been a return to solvency. Furthermore, the damage to the reputation of a business rescue practitioner with such a mind-set would negatively affect his or her ability to obtain future assignments. On the contrary, a minority of the experts argued that if the economics do not measure up for business rescue practitioners, quality business rescue practitioners will not be attracted to the profession, and the risk for the profession would simply be too high to ignore adequate 
TABLE 7: Additional business rescue success criteria.

\begin{tabular}{llll}
\hline Success indicator & Variable & $\begin{array}{l}\text { Panel } \\
\text { response (\%) }\end{array}$ & Note †' \\
\hline $\begin{array}{l}\text { A measurement based on the public } \\
\text { interest ('PI') score to determine } \\
\text { the number of PI points 'saved' } \\
\text { or 'rescued' }\end{array}$ & $\begin{array}{l}\text { Agree \& strongly } \\
\text { agree } \\
\text { Disagree \& } \\
\text { strongly disagree }\end{array}$ & 64 & 15 \\
$\begin{array}{l}\text { Proximity of actual outcome } \\
\text { to that estimated in plan } \\
\text { (e.g. cents or rand dividend) }\end{array}$ & $\begin{array}{l}\text { Agree \& strongly } \\
\text { agree }\end{array}$ & 82 & 16 \\
& $\begin{array}{l}\text { Disagree \& } \\
\text { strongly disagree }\end{array}$ & 18 & \\
\hline
\end{tabular}

$\dagger$, Description provided in the text

compensation. The researchers concluded that this indicator was not supported by the panel and should therefore be excluded from the final list of success indicators.

\section{Note 5}

The results show that the panellists mainly disagree on the matter. Those in favour of the indicator argued that it is likely that it may indicate success; however, acceptance by creditors is only the first step in the process and the business rescue plan must be substantially implemented for the rescue to be a success. Furthermore, without an approved plan, the business rescue practitioner will not be able to implement anything. Those against the inclusion of the indicator used the same argument, namely that acceptance by creditors is only a step in the business rescue process, not an indicator of its success. Since the panel did not reach consensus on the indicator, and based on the above arguments, the researchers concluded that the acceptance of the plan is one of the procedures of business rescue, but not an indication of business rescue success. The indicator should therefore be excluded from the final list of success indicators.

\section{Note 6}

The results show that the panel was divided on whether the business rescue can be considered a success if the approved plan was only partially implemented. Those in favour of this success indicator argued that if a partial implementation beat liquidation, the business rescue was worthwhile. On the contrary, one expert said:

'In order to achieve success the business rescue practitioner must submit an amended plan to creditors. The amended plan should then reflect the partial implementation and ask creditors for approval of the amended plan. Only if that amended plan is approved by creditors may the implementation of that amended plan be regarded as a success.' (Expert 104957, 2016)

One panellist bluntly said:

'You can't be half pregnant! Either it (the plan) is implemented or not.' (Expert 104946, 2016)

Although the researchers could see the merit in considering a partial implementation if it beats liquidation, the panel could not reach consensus on the matter. The researchers therefore concluded that it should be excluded as an indicator of success under Goal 1. However, if partial implementation beats liquidation, it may indicate a success under Goal 2 (better return to creditors) as opposed to Goal 1 (going concern).

\section{Note 7}

The panel unanimously agreed that it indicates success if a plan was substantially implemented.

\section{Note 8}

The panel unanimously agreed that if the company exited business rescue as a going concern, it indicates success. One expert referred to this as a 'super success'.

\section{Note 9}

All of the panellists, except one, agreed with this indicator. The expert commented that:

'this is not enough, the business model needs to demonstrate viability as a business.' (Expert 105536, 2016)

In essence the expert agreed that business rescue is not just about delivering a going concern upon exiting business rescue, but delivering an economically viable business that will survive in the foreseeable future. The indicator is therefore included in the list of business rescue success indicators.

\section{Note 10}

Three of the experts disagreed with the indicator. Two experts argued that business rescue practitioners do not drive the final outcome after they step away. Furthermore, if the business has a chance of sustainability, the business rescue was successful. The researchers understand that, after termination of business rescue, the performance of the company is no longer in the hands of the practitioner. However, this is irrelevant. Business rescue success is not intended to measure the quality of the practitioner, but rather the effectiveness of the business rescue legislation. One should therefore be able to evaluate the company separately from the practitioner.

One expert commented that:

'... it depends on the type of business.' (Expert 105536, 2016)

For example:

'... a mining project would need to show viability over a longer period.' (Expert 105536, 2016)

The latter comment can be interpreted as showing that the expert actually agrees that performance after business rescue termination should be evaluated, but that the time period should be carefully considered.

Although the remaining two experts did not agree with this success indicator, a high level of consensus was still reached on this indicator, and the researchers concluded that the indicator should be included in the final list of success indicators.

\section{Note 11}

Two panellists did not agree with this indicator. The one expert argued that the company could perform in tandem with the market and still fail. Equally, it could lag the market but still survive'. The other expert argued that in the long term the company will have an opportunity to become 
successful once again, thereby indicating that performance over the long term is disassociated from its initial successful going concern exit from the business rescue proceedings. Although the above-mentioned two experts did not agree with this success indicator, a high level of consensus (88\%) was still reached, demonstrating that the majority of panellists deemed this indicator to be appropriate. The indicator should therefore be included in the final list of success indicators.

Table 5 presents the responses to the success indicators with respect to Goal 2, namely a better return to creditors than under immediate liquidation.

The notes below refer to the applicable indicators in Table 5 and state the reasons for instances where the panellists did not reach $100 \%$ consensus.

\section{Note 12}

The panel agreed unanimously that if the approved plan (to maximise the return to creditors) were implemented substantially, it would indicate success. One expert suggested that the indicator should read 'to optimise the return to creditors' and explained as follows:

'Maximising may see a higher dividend, but it could be payable on a never-never basis. It would be preferable for creditors to receive a smaller dividend but receive the cash earlier and bring about certainty.' (Expert 104957, 2016)

The authors agree that the optimisation of the return to creditors takes cognisance of the time value of money, an aspect that could be significant given the lengthy period it takes to conclude the business rescue proceedings. However, since the questionnaire-circulated indicator referred to 'maximise', the indicator will be included as such but with a note indicating that it should include a consideration of the time value of money.

\section{Note 13}

All of the experts, with the exception of three, agreed to this indicator of success. The three dissenting experts argued that if a plan presupposes the liquidation of the business as the rescue, the business rescue practitioner should rather terminate business rescue and apply for liquidation. One expert said that a:

'liquidation under a plan or immediate liquidation is still liquidation'. (Expert 104957)

The expert suggested that the business rescue plan should be to: 'realise assets and then to de-register the company', [because] 'that is totally different to liquidation'. (Expert 104957)

The same expert agreed that:

'if the proceeds realised from the implementation of a business rescue plan exceeds that of a liquidation, then there is success according to the Act (i.e., Chapter 6).' (Expert 104957)

It is evident that the word 'liquidation' may have been misleading to some experts, as 'liquidation' in its true sense means that the company is forced to cease operations and liquidate its assets at usually low fire-sale prices (Accounting Tools 2016). The suggested change in wording is valid, and will be incorporated in the final list of success indicators.

\section{Note 14}

The panel of experts, except one, agreed that this route enables the business to survive as a going concern, safeguards some employment, and allows continued trading in a different company. One agreeing expert mentioned that Chapter 6 is called 'business rescue', not 'company rescue'. Therefore, preserving the business should be regarded as success. The dissenting expert argued that:

'... there is no legal requirement for the key operations to remain alive, provided the other objective of business rescue is met, namely to realise value better than in liquidation.' (Expert 105536, 2016)

Due to the high level of consensus reached, the indicator will be included as an indicator of business rescue success.

Table 6 presents the results on the one implicit goal of business rescue, namely to save a substantial number of jobs.

All the experts agreed regarding the above-mentioned indicator of success. The dissenting expert commented as follows:

'The number of jobs saved alone is not an indicator. The company could shed the majority of the jobs but still emerge sustainable thereafter. Perhaps saved as many jobs as possible or preserved some jobs and future job opportunities for employees.' (Expert 105536, 2016)

The comment is indeed valid. What the researchers actually had in mind was that this measure should not be used on its own, but with the other 'going concern' measures, and that some jobs (or as many as possible) should be saved. It is clear that it was only the wording of this statement that misled this expert, but that he or she in essence agreed that the number of jobs saved should be considered in the measurement of success. The researchers therefore conclude that consensus was reached and that the indicator will be included in the final list of indicators.

The next section addresses the additional indicators of success that were proposed by the business rescue experts.

\section{Additional success indicators}

Some of the panel members suggested two new success indicators, which had not been identified in either the literature or the pilot interviews before. These indicators were included in Questionnaire 2, and feedback from the rest of the panel members was requested. A few panellists, unfortunately, did not respond to the questions on these additional success criteria. Although the original panel size consisted of 16 participants, only 12 experts responded on the two additional indicators listed in Table 7. However, even though only 12 experts responded, the panel size was still big 
enough to draw adequate conclusions from, since it fell within the range of acceptable panel sizes for a Delphi study, namely a panel size of 10-18 individuals (Okoli \& Pawlowski 2004:19).

\section{Note 15}

One of the two experts who suggested this indicator, posited that:

\begin{abstract}
'... a business rescue with a PI score of 2000 at the start cannot be equated to one with a PI score of say 100 at the outset. There is a weighting in terms of the PI score that needs to be taken into consideration.' (Expert 104831, 2016)
\end{abstract}

The PI score is determined by allocating points based on the number of employees, turnover, liabilities and beneficial security holders (Republic of South Africa 2011).

A total of $64 \%$ of the experts agreed that an indicator based on the PI score should be used. Experts who disagreed commented that the measure is limited to the legal entity, and if the business is sold and all jobs are transferred to a new entity the remaining PI score would be zero. Furthermore, a rescue usually includes the compromise of debt and staff retrenchments, and as such would reduce the PI score. They argued that the rescue of a business cannot be measured on the PI score which is a measurement tool to measure something totally different from business rescue.

The idea is novel and unique in a South African context and for this reason, supported by some experts, the researchers decided to include the PI score (points saved or rescued) as an indicator of a successful business rescue. However, for this type of indicator to be accepted with more confidence, additional research is needed to develop a customised PI scorecard or verifier with guidance on how it should be interpreted in a business rescue context.

\section{Note 16}

This indicator of success drew 83\% agreement from the business rescue experts. One expert said this is

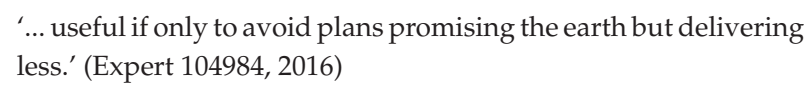

The expert further suggested that, as an alternative, the delta between liquidation estimated return and actual business rescue return might work as well, but warned that liquidation calculations may be stated at artificially low levels to justify support for the plan. Those against the indicator argued that a comparison to liquidation would be better, but such an approach also negates other issues such as jobs saved, ongoing customer support and how the split is made between different classes of creditors. Another argument was that an estimation is just that - a potential view based on assumptions with most projections that will deviate over time due to market forces and unexpected changes integral to the business environment.
The high level of consensus among the experts who commented on the indicator shows that ultimately the return to creditors is an important indicator and therefore the indicator should be included in the final list of success indicators.

After taking all of the feedback received from the panel into consideration, the researchers were able to answer the research questions and reach a conclusion on the research aim. The conclusion and recommendations are documented in the next section.

\section{Conclusion and recommendations}

The aim of the study was to reach a high level of consensus on what the expert business rescue practitioners would consider to be the indicators of a successful business rescue. By using the Delphi research technique the opinions of senior business rescue practitioners were obtained, corroborated and evaluated in the relevant context.

The results of this study show that, at the date of termination of business rescue, a successful business rescue under Goal 1 (going concern) is indicated when:

- the business rescue plan was substantially implemented;

- the distressed company exited business rescue as a going concern;

- the rescue saved as many jobs as possible;

- business rescue points are saved or rescued (when using the public interest score); and

- the actual outcome of the business rescue compares well to that estimated in the business rescue plan, taking into account the time value of money as well.

Furthermore, the results show that success also includes evaluating the performance of the company after substantial implementation. Ultimately, a successful business rescue is indicated when:

- the company, after exiting business rescue, proves to be profitable in the short to medium term (e.g. based on verifiers such as profit margins, return on assets and cash flows);

- the company, after exiting business rescue, proves to be economically viable in the short to medium term (e.g. measured by whether the company subsequently re-filed for business rescue); and

- the company, after exiting business rescue performs in the long term on par with market expectations (if listed), or it matches the performance of peer companies (if it is an unlisted company).

When a business rescue practitioner pursues Goal 2 (better return to creditors), the results show that if a company's assets were realised under a business rescue plan and the company was then deregistered, it is an indicator of success if:

- the approved plan (to maximise return to creditors) was substantially implemented, and 
- the return received under the business rescue proceedings (cents or Rand dividend) proves to be more than the return that would have been received under immediate liquidation.

It should be noted that when business rescue procedures are used merely to bring about a piecemeal sale of assets and deregistration of the company, the completion of this plan cannot be considered an indication of success. Such a strategy indirectly adds to the liquidation statistics, and is not in line with the spirit of Chapter 6 .

The results of the study were able to show that international indicators of success could also be used to indicate the success of business rescue in a South African context. Furthermore, additional indicators have been identified, of which one could be unique to the South African context. This study makes a valuable contribution to the theory of what constitutes a business rescue success. The research revealed that business rescue experts are in need of a business rescue scorecard or measurement tool. Further research into developing specific measures, or verifiers, of these success indicators is needed that can form the basis of such a scorecard or measurement tool. Moreover, the scorecard or measurement tool can also rank the verifiers to assist with the calculation of relevant success rates in a consistent and comparable manner.

\section{Limitations to this study}

The study investigates success from the viewpoint of senior business rescue practitioners, being experts actively engaged in business rescue endeavours on a day-to-day basis. However, the authors acknowledge that there may also be expert viewpoints of other stakeholders, such as restructuring specialists at major lending institutions. Further research into their views and opinions of success could only add to measures that can be used to develop the above-mentioned scorecard or measurement tool.

'Measure what is measurable, and make measurable what is not so' - Galileo Galilei

\section{Acknowledgements}

We would like to thank the anonymous reviewers whose comments and suggestions have helped to strengthen the article.

\section{Competing interests}

The authors declare that they have no financial or personal relationships that may have inappropriately influenced them in writing this article.

\section{Authors' contributions}

C.L. focused on the strategic direction and structure of the article. S.C. developed the research instrument, analysed the data and wrote the first draft of the manuscript. Both authors worked on the data collection and interpretation of the results.

\section{References}

Accounting Tools, 2016, viewed 25 October 2016, from http://www.accountingtools. com/going-concern-principle

Anonymous Expert A, 2016, Personal interview, 11 March, Stellenbosch, South Africa. Anonymous Expert B, 2016, Personal interview, 18 March, Durbanville, South Africa.

Bezuidenhout, P.T.J., 2012, 'A review of business rescue in South Africa since implementation of the Companies Act (71/2008)', Masters dissertation, North-West University, South Africa.

Bradstreet, R., 2011, 'The new business rescue: Will creditors sink or swim?', South African Law Journal 128(2), 352-380.

Burke-Le Roux, A. \& Pretorius, M., 2017, 'Exploring entrepreneurial learning during formal business rescue processes: Insights from the South African experience', SA Journal of Human Resource Management 15(1), 1-15. https://doi.org/10.4102/ sajhrm.v15i0.733

Calitz, J. \& Freebody, G., 2016, 'Is post-commencement finance proving to be the thorn in the side of business rescue proceedings under the 2008 companies act?', De Jure 49(2), 265-287. https://doi.org/10.17159/2225-7160/2016/ v49n2a5

Commission, 2014, Annual report 2013/2014, viewed 10 October 2017, from http:// www.thedti.gov.za/parliament/2014/CIPC_AR2014.pdf

Companies and Intellectual Property Commission (CIPC), 2015, Licensed business rescue practitioners, viewed 30 November 2015, from http://www.cipc.co.za/ files/5114/2364/7533/Licensed_Business_Rescue_Practitioners_11_February 2015.pdf

Conradie, S. \& Lamprecht, C., 2015, 'Business rescue: How can its success be evaluated at company level?', Southern African Business Review 19(3), 1-29.

Deloitte, 2017, South Africa restructuring outlook survey results 2017 - Seeing through the fog, viewed 02 October 2017, from https://www2.deloitte.com/za/ en/pages/finance/articles/sa-restructuring-outlook-survey-2017.htm

Dudley, E., Plumly, M. \& Knoblock, M., 1999, 'How do you measure success?', Internal Auditor 56(2), 58-63.

Du Preez, W., 2013, 'The status of post-commencement finance for business rescue in South Africa', Masters dissertation, University of Pretoria, South Africa.

Gordon, T.J., 1994, 'The Delphi method', Futures Research Methodology 2(3), 1-30, Millennium Project Publications, United Nations.

Jones, P., 2012, What is the difference between a measure and an indicator?, viewed 01 November 2015, from http://www.excitant.co.uk/what-is-the-differencebetween-a-measure-and-an-indicator/

Lebeloane, V.M., 2017, 'An evaluation of business rescue plans based on business rescue principles and guidelines to determine leading indicators of business rescue outcomes', Masters dissertation, University of Pretoria, South Africa.

Loubser, A., 2013, 'Tilting at windmills? The quest for an effective corporate rescue procedure in South African law', SA Mercantile Law Journal 25(4), 437-457.

Maphiri, M.C., 2015, 'Business rescue in South Africa and its practical application to SME's (small to medium enterprises)', Masters dissertation, University of Cape Town, South Africa.

Mouton, J., 2001, How to succeed in your master's and doctoral studies: A South African guide and resource book, Van Schaik Publishers, Pretoria, South Africa.

Naidoo, P., 2017, 'Issues of quality in qualitative research' lecture notes, Cape Town Qualitative Methodology workshop, University of the Free State, delivered 16 September 2017.

Naidoo, T., 2016, 'Business rescue in South Africa: An exploration of the views of business rescue practitioners', Masters dissertation, University of the Witwatersrand, South Africa.

Noomé, J., 2014, 'The sources and obstacles of post-commencement finance in South Africa: A comparison with the United Kingdom and Australia', Masters dissertation, University of Johannesburg, South Africa.

Okoli, C. \& Pawlowski, S.D., 2004, 'The Delphi method as a research tool: An example, design considerations and applications', Information \& Management, 42(1), 15-29. https://doi.org/10.1016/j.im.2003.11.002

Olalere, T., 2011, 'Methodology in accounting research: A critique of taxonomy'. Available at SSRN: https://ssrn.com/abstract=1921192 or http://dx.doi.org/ $10.2139 /$ ssrn. 1921192

Oxford Dictionary, 2017, Definition of indicator in English, viewed 21 September 2017 from https://en.oxforddictionaries.com/definition/indicator

Pretorius, M., 2015, Business rescue status quo report, viewed 25 October 2016, from http://www.cipc.gov.za/files/4714/2866/7900/Report_Number_3_ammended 30032015.pdf

Pretorius, M. \& Rosslyn-Smith, W., 2014, 'Expectations of a business rescue plan: International directives for Chapter 6 implementation', Southern African Business Review 18(2), 108-139.

Prior, V., 2014, 'A pre-assessment checklist to filing for business rescue in South Africa', Masters dissertation, University of Pretoria, South Africa. 
Reineck, J.P., 2015, 'A private equity structure to facilitate the effective postcommencement financing of business rescue', Masters dissertation, University of Cape Town, South Africa.

Republic of South Africa, 2008, Companies Act, no 71 of 2008, Government Printer, Pretoria, South Africa.

Republic of South Africa, 2011, Companies Act Regulations, 2011, Government Printer, Pretoria, South Africa.

Searle, R., 2013, 'Will there be a need for informal loan workouts? A question from chapter 6 of the new companies act', Masters dissertation, University of the Witwatersrand, South Africa.
Skulmoski, G.J., Hartman, F.T. \& Krahn, J., 2007, 'The Delphi method for graduate research', Journal of Information Technology Education 6, 1-21. https://doi.org/10.28945/199

Swart, W.J.C., 2014, 'Business rescue: Do employees have better (reasonable) prospects of success? Commentary on Employees of Solar Spectrum Trading 83 (Pty) Limited v AFGRI Operations Limited (North Gauteng High Court, Pretoria (unreported) 2012-05-16 Case no. 6418/2011; 18624/2011; 66226/2011; 66226A/11): Cases', Obiter 35(2), 406-420.

Vanderstraeten, M., 2016, 'Business rescue: Feature', Without Prejudice 16(7), 1-34.

Yin, R.K., 2009, Case study research. Designs and methods: Applied social research methods, 4th edn., Sage, London, UK. 